\title{
The Effects of Yoga Practice on Practitioners' Environmental Behaviours \& Sustainability
}

\author{
Aglaia Zafeiroudi (Corresponding author) \\ Department of Physical Education and Sport Science \\ University of Thessaly, Karies, Trikala, 42100, Greece
}

Tel: 30-243-104-7004Ｅ-mail: aglaiazaf@hotmail.com

\begin{abstract}
Mathildi Pipinia
Department of Physical Education and Sport Science

University of Thessaly, Karies, Trikala, 42100, Greece

Tel: 30-243-104-7004Ｅ-mail: mppinia@gmail.com
\end{abstract}

\begin{abstract}
Georgia Yfantidou
Department of Physical Education and Sport Science

Democritus University of Thrace, Komotini, 69100, Greece
\end{abstract}

Tel: 30-253-103-9709Ｅ-mail: gifantid@ phyed.duth.gr

\author{
Sotirios Georgomanos \\ Department of Physical Education and Sport Science \\ University of Thessaly, Karies, Trikala, 42100, Greece \\ Tel: 30-243-104-7004Ｅ-mail: geosotlab@gmail.com
}

Received: June 30, 2021 Accepted: July 22, $2021 \quad$ Published: July 28, 2021

doi:10.5296/emsd.v10i3.18894 URL: https://doi.org/10.5296/emsd.v10i3.18894

\section{Abstract}

Yoga philosophy includes ethical codes of conduct, guidelines, meditation and other practices 
that respect the Earth, its natural resources, humans and other living beings. The purpose of the present study was to investigate the effects of yoga practice on practitioners' environmental behaviours and sustainability. A total of 195 adults (66 men and 129 women) from two cities in Greece participated in this study. The participants completed the General Environmental Responsible Behaviour scale (Zafeiroudi \& Hatzigeorgiadis, 2013) and provided additional information about their personal lifestyles, leisure activity preferences and frequency of participation in outdoor activities. Independent sample T-test analysis was used to investigate differences between practitioners' demographics and the General Environmental Responsible Behaviour scale as the dependent variable. The results indicated statistically significant differences in environmental behaviour scores among practitioners in different yoga demographics. On the basis of yoga philosophy, the study findings suggested that participation in yoga practices strengthens beliefs, behaviours and awareness regarding the environment. The individual values taught by the philosophy of yoga also foster friendlier attitudes and behaviours towards the environment. Moreover, the findings indicated that yoga practice might be an effective supplement and tool to promote green sustainable programs currently run by environmental and social organizations.

Keywords: Environmentalism, Ecology, Yoga philosophy, Meditation, Mindfulness, Leisure, Outdoor activities

\section{Introduction}

Yoga is not just a physical practice; it is the 'science' of healthy living (Zafeiroudi, 2021; Cramer, Sibbritt, Park, Adams, \& Lauche, 2017; Basavaraddi, 2015). It combines physical and spiritual disciplines through the harmony of the body, mind and spirit. Patanjali's Yoga Sutras, written 2,500 years ago, propose a code of conduct in the form of eight steps that outline a spiritual way of life leading to love and respect for individuals, nature and all living beings (Zafeiroudi, 2018a; Zafeiroudi, 2018b; Malhotra, 2001). The philosophy of yoga includes Yamas and Niyamas, general and individual moral thoughts, and practices enhancing self-improvement and a virtuous life (Zafeiroudi, 2021; Iyenger, 1979). Self-discipline, control of passions and the correction of mistakes lead to inner clarity and freedom (Kumar, 2017). After gaining respect and love for themselves, people are then able to dedicate themselves to helping others, and protecting nature and the environment (Bhagwat, 2008).

Environmental sustainability is not frequently promoted by modern yoga teachers and studios in Western countries. Modern yoga is synonymous with the development of the physical body, with an emphasis on asana, the poses and fitness. In the face of the myriad environmental problems currently plaguing our planet (Hill, 2020; Zafeiroudi, 2020), the notion of ecology and protection of nature appears to be directly associated with the philosophy of yoga and the yogic way of life. The teachings of yoga include principles and practices of both the mind and body that, when applied, can change how people treat the environment. Can practicing yoga help make the world a better place to live? Can yoga inspire environmental consciousness for a better Earth?

The broader purpose of the present study was to explore how yoga and environmental sustainability are related. The main objective was to investigate whether participation in a 
yoga practice changes daily behaviour towards the environment through actions such as recycling, tree planting and the consumption of organic and natural foods. The secondary objectives of the study were to investigate yoga practitioners' changes in environmental behaviours depending on the level of yoga experience, type of leisure activity participation and frequency of participation in outdoor activities.

\subsection{The Definition of Yoga}

Yoga is an ancient art with roots in the ancient traditions of the East, specifically India. Information about yoga is derived from the pre-Vedic period, dating to $2500 \mathrm{BC}$, from texts and related works written in the Vedic language Sanskrit. Yoga does not discriminate: anyone can engage in yoga regardless of their religion, nationality, culture, age, gender or social status. Through yoga, practitioners experience physical benefits as the body becomes stronger and more flexible, and the cardio-respiratory, circulatory, digestive and hormonal systems undergo improvements (Agarwal, 2018). Other yoga benefits include calmness, and relief from stress, tension and anxiety, thus supporting mental cohesiveness and composure (Varambally \& Gangadhar, 2016). Yoga practices have been developed to allow for purification of the body, mind and emotions to bring about mental vigilance (Brinkley, 2010). According to Thurston and Bloyce (2020), yoga helps practitioners relax, balance their emotions, and perceive the freedom of the mind and the connection of the body to movement and breathing.

Yoga involves the true connection of people with themselves: the word 'yoga' has the Sanskrit root 'yuj', which means to unite or connect. Thus, practitioners connect with their souls, their nature and the higher powers within them, with the ultimate goals of self-concentration and meditation (Zafeiroudi, 2018a; Pandey, Ajinkya \& Rajesh, 2017). Hatha yoga postures contribute to this connection and balance among the body, mind, consciousness and soul. After gaining respect and love for themselves, people can then dedicate themselves to helping others, protecting nature and the environment, and handling life in a positive way.

\subsection{Yoga Philosophy and the Eight Steps of Patanjali}

The Yoga Sutras, which were collected and documented in 400-200 BC by Patanjali, are a series of teachings ('sutra' means strand) that are joined together like the beads of a rosary (Hartranft, 2002). Patanjali compiled and codified the traditional yoga techniques that lead to true connections of humans with themselves, their surroundings and their goals of mental freedom (Zafeiroudi, 2018a; Basavaraddi, 2015). The eight steps leading to absolute balance and awareness are as follows: Yama (ethical restraints), Niyama (ethical observances), Asana (physical poses), Pranayama (control of breathing), Pratyahara (withdrawal of senses), Dharana (concentration), Dhyana, (meditation) and Samadhi (superconsciousness).

The Yamas include five moral principles and codes of conduct concerning the surrounding world and people's interactions with it. They state that prosperity occurs when non-violence (Ahimsa), honesty and truthfulness (Satya), no stealing, generosity of emotion (Asteya), continence (Brahmacharya) and non-possessiveness (Aparigraha) are met. According to yogic 
life, these codes of conduct should be part of daily life (Sapphire, 2018). The Niyamas include another five codes of conduct promoting the observance of personal and individual practices associated with self-training, control and discipline (Zafeiroudi, 2018b). They act as a means of purity (Saucha), contentment (Santosha), austerity (Tapas), self-study (Swadhyaya) and devotion (Isvara Pranidhana). Asanas and pranayama prepare the physical body through practice and foster a connection with the breath. Finally, pratyahara, dharana, dhyana and samadhi involve practice in effectively connecting the body, mind, soul and spirit.

\subsection{Yoga, Leisure, Environment and Sustainability}

Many researchers have studied the relationships among mindfulness, meditation and yoga practice with respect to nature, and the environment and its protection. According to Bhagwat (2008), the philosophy of yoga offers ethical codes through Yamas and Niyamas that have environmental, social and economic applications and thereby influence individual behaviour to protect nature and sustainability. Bhagwat (2008) also suggests specific examples of thoughts and behaviour regarding the first two steps of Patanjali: showing respect to the Earth and all living beings. More specifically, practicing Ahimsa (non-violence) involves eating less meat and decreasing consumption of animal products. Practicing Aparigraha (non-possessive) involves evaluating the consumption of things, recycling and conserving natural resources.

Weisner and Cameron (2020) have demonstrated a relationship between yoga and environmental behaviour: improving concentration and sensory awareness through meditation and yoga brings the physical body closer to nature by causing more environmentally friendly behaviour. Furthermore, Ericson, Kjønstad and Barstad (2014) have stated that consciousness significantly contributes to sustainability by enhancing the quality of life and well-being. In particular, the practices of meditation and yoga improve spirituality, separate human beings from matter, strengthen inner values and lead to more environmentally sustainable behaviour. The same researchers have suggested that meditation and yoga practices can be applied in schools and other organizations to protect the environment. Improving consciousness and mindfulness reinforces 'greener' behaviour, including ecological actions based on a respect for nature and life resources (Amel, Manning, \& Scott, 2009).

Many other researchers have referred to the spiritual elements developed and cultivated by meditation and yoga, such as self-awareness (Vago, 2014), self-knowledge (Carlson, 2013), changes in cultural values (Tibbs, 2011), an increase in happiness (O'Brien, 2008) and de-automation (Kang, Gruber, \& Gray, 2013). Spiritual growth through yoga practice helps people achieve a better quality of life and well-being, thus leading to a more environmentally friendly and sustainable lifestyle.

Thurston and Bloyce (2020) have reported that yoga is a worldwide leisure activity that offers relaxation and excitement, stimulates emotions and feelings of pleasure, and has replaced many of the sports and activities in which people used to participate during their free time. Sumner (2018) has linked sustainable leisure and sustainable communities (the places where people want to live and work now and in the future; page 4), explaining that people can 
participate in leisure activities such as clean-up programs, renewable energy projects, picking up trash, ecotourism, and volunteering with groups and associations carrying out sustainable activities.

Outdoor recreational activities are a form of physically active leisure (Zafeiroudi, 2014). Many studies have asserted that participation in outdoor recreation activities, such as trekking, bicycling, swimming and skiing, are associated with environmentalism and sustainability in both adults and children (Zafeiroudi, 2020; Harbrow, 2019; Pavlidis, Zafeiroudi \& Kouthouris, 2018). Participation in outdoor activities has been shown to create interconnections between humans and nature, to improve knowledge of sustainability, and to foster eco-friendly actions and environmental awareness.

The present study aimed at further demonstrating that the practice of yoga as a leisure activity generates new habits and lifestyles that support ecological approaches for better living and a more sustainable future.

\section{Method}

\subsection{Participants}

A total of 195 individuals involved in yoga practice participated in this study. The survey occurred in the cities of Trikala (32.8\%) and Chios (67.2\%) in Greece. The participating practitioners completed a questionnaire containing the General Environmental Responsible Behaviour scale; demographic information on gender, age, marital status; and additional information on personal behaviours such as: i) level of yoga experience ii) types of participation in leisure activities and iii) frequency of participation in outdoor activities. The frequency of participation in outdoor recreation activities was assessed with the question of "How often do you normally participate in outdoor activities during per month (such as hiking, orienteering, mountain hiking, climbing, mountaineering, rafting, kayaking, canoeing, mountain biking, skiing, sailing or horseback riding), in a typical year?" Responses were given on a two-point scale (1=low, $2=$ middle). Data are presented in Table 1.

Table 1. Sample Demographics

\begin{tabular}{|l|l|l|}
\hline Residents & Gender & Age Subgroups \\
\hline Trikala: 64 (32.8\%) & Men: 66 (33.8\%) & $1^{\text {st }}$ group (>29): 54 (27.7\%) \\
\hline Chios: 131 (67.2\%) & Women: 129 (66.2\%) & $2^{\text {nd }}$ group (30<39): 48 (24,6\%) \\
\hline $\begin{array}{l}\text { Marital Status } \\
107(54.9 \%) \text { Single }\end{array}$ & & $3^{\text {rd }}$ group $(40<49): 45(23.1 \%)$ \\
$88(45.1 \%)$ Married & & $4^{\text {rd }}$ group $(50<): 48(24.6 \%)$ \\
\hline Yoga Experience & Types of Leisure Participation & Outdoor Frequency \\
\hline Low & Active & Low rates \\
$130(66,7 \%)$ & $93(47,3 \%)$ & $105(53,8 \%)$ \\
High & Passive & Middle rates \\
$65(33,3 \%)$ & $103(52,8 \%)$ & $90(46,2 \%)$ \\
\hline
\end{tabular}




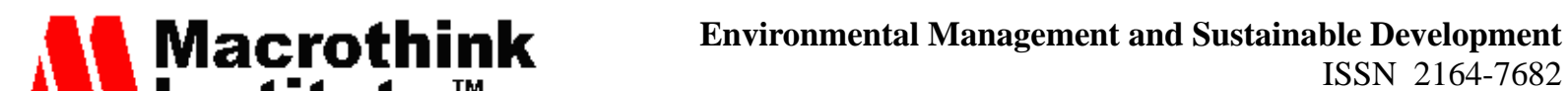 \\ 2021, Vol. 10, No. 3}

\subsection{Research Instrument}

Responsible Environmental Behaviour was used as the dependent variable in the study. The Greek version of the Responsible Environmental Behaviour scale (Zafeiroudi \& Hatzigeorgiadis, 2013; Zafeiroudi \& Hatzigeorgiadis 2012) was used to assess environmental behaviour. The scale comprises ten items assessing the extent to which individuals engage in actions to protect the environment, through the following questions: "Do you: 1) participate in environmental events, 2) participate in actions of cleaning up forests, beaches or outdoor areas, 3) participate in meetings of environmental organizations, 4) participate in tree planting, 5) seek information on addressing environmental pollution, 6) reduce the use of energy recourses in your everyday life, 7) prefer products that have lower polluting effects, 8) prefer products in recyclable packages/containers, 9) support politicians who are strongly concerned about environmental problems and 10) support environmental publications and TV programs?" The scale consisted of two relevant factors: individual environmental action, with seven items (e.g., how often do you use products in recyclable packages/containers), and group environmental action, with three items (e.g., how often do you participate in environmental events). Answers were given on a five-point Likert scale ( $1=$ never to $5=$ every day). The internal consistency of the scale was tested successfully (Cronbach's $\alpha=.85$ ).

\section{Results}

\subsection{Statistics and Data Analysis}

Descriptive statistics was used to assess the sample for environmental responsibility practices. Remarkably, all Greb items were acceptable as behaviours by yoga practitioners. The scores revealed that Greb 6 and Greb 7 were the most important environmental items according to the yoga practitioners. The three objectives of the study were tested with three independent-sample t-tests. T-tests were used to examine the ten Greb items as the dependent variables for possible differences with respect to the three independent variables in the study (Table 2). 
Table 2. Greb scale item data and t-test results for three independent study variables

\begin{tabular}{|c|c|c|c|c|c|c|c|c|c|c|}
\hline & $\begin{array}{l}\text { Greb } \\
1\end{array}$ & $\begin{array}{l}\text { Greb } \\
2\end{array}$ & $\begin{array}{l}\text { Greb } \\
3\end{array}$ & $\begin{array}{l}\text { Greb } \\
4\end{array}$ & $\begin{array}{l}\text { Greb } \\
5\end{array}$ & $\begin{array}{l}\text { Greb } \\
6\end{array}$ & $\begin{array}{l}\text { Greb } \\
7\end{array}$ & $\begin{array}{l}\text { Greb } \\
8\end{array}$ & $\begin{array}{l}\text { Greb } \\
9\end{array}$ & $\begin{array}{l}\text { Greb } \\
10\end{array}$ \\
\hline$M$ & 2,6 & 2,4 & 2,5 & 2,9 & 3,6 & 3,7 & 3,7 & 2,8 & 1,8 & 3,6 \\
\hline$( \pm$. SD) & 1,0 & 1,0 & 1,1 & 1,2 & 1,0 & 1,0 & 1,1 & 1,3 & 1,0 & 1,0 \\
\hline $\begin{array}{l}\text { Yoga } \\
\text { Experience }\end{array}$ & $\begin{array}{l}\text { Greb } \\
1 \\
\end{array}$ & $\begin{array}{l}\text { Greb } \\
2 \\
\end{array}$ & $\begin{array}{l}\text { Greb } \\
3 \\
\end{array}$ & $\begin{array}{l}\text { Greb } \\
4 \\
\end{array}$ & $\begin{array}{l}\text { Greb } \\
5\end{array}$ & $\begin{array}{l}\text { Greb } \\
6 \\
\end{array}$ & $\begin{array}{l}\text { Greb } \\
7\end{array}$ & $\begin{array}{l}\text { Greb } \\
8 \\
\end{array}$ & $\begin{array}{l}\text { Greb } \\
9\end{array}$ & $\begin{array}{l}\text { Greb } \\
10\end{array}$ \\
\hline Low & $\begin{array}{l}2.43 \\
( \pm .89) \\
\end{array}$ & $\begin{array}{l}2.36 \\
( \pm 1,1) \\
\end{array}$ & $\begin{array}{l}2.36 \\
( \pm 1.13)\end{array}$ & $\begin{array}{l}2.83 \\
( \pm 1.2)\end{array}$ & $\begin{array}{l}3,83 \\
( \pm 1,0) \\
\end{array}$ & $\begin{array}{l}3.7 \\
( \pm .98) \\
\end{array}$ & $\begin{array}{l}3.9 \\
( \pm 1.17)\end{array}$ & $\begin{array}{l}2.9 \\
( \pm 1.3)\end{array}$ & $\begin{array}{l}1.8 \\
( \pm 1.0)\end{array}$ & $\begin{array}{l}3.7 \\
( \pm 1.1) \\
\end{array}$ \\
\hline High & $\begin{array}{l}3.12 \\
( \pm 1.2) \\
\end{array}$ & $\begin{array}{l}2.66 \\
( \pm .90) \\
\end{array}$ & $\begin{array}{l}2.87 \\
( \pm 1.13)\end{array}$ & $\begin{array}{l}3.12 \\
( \pm 1.2) \\
\end{array}$ & $\begin{array}{l}3.4 \\
( \pm 1,0) \\
\end{array}$ & $\begin{array}{l}3.6 \\
( \pm 1.0) \\
\end{array}$ & $\begin{array}{l}3,5 \\
( \pm 1.0)\end{array}$ & $\begin{array}{l}2.66 \\
( \pm 1.3) \\
\end{array}$ & $\begin{array}{l}1.8 \\
( \pm 1.0) \\
\end{array}$ & $\begin{array}{l}3.4 \\
( \pm 1.0) \\
\end{array}$ \\
\hline$t / p$ & $\begin{array}{l}-4.85 * \\
p<.001\end{array}$ & $p=n . s$. & $\begin{array}{l}-2.94^{*} \\
\mathrm{p}<.01 \\
\end{array}$ & $p=n . s$. & $\begin{array}{l}-2.70 * \\
\mathbf{p}<.01\end{array}$ & $p=n . s$. & $p=n . s$. & $p=n . s$. & $p=n . s$. & $p=n . s$. \\
\hline $\begin{array}{l}\text { Type of } \\
\text { Leisure }\end{array}$ & $\begin{array}{l}\text { Greb } \\
1 \\
\end{array}$ & $\begin{array}{l}\text { Greb } \\
2\end{array}$ & $\begin{array}{l}\text { Greb } \\
3 \\
\end{array}$ & $\begin{array}{l}\text { Greb } \\
4 \\
\end{array}$ & $\begin{array}{l}\text { Greb } \\
5\end{array}$ & $\begin{array}{l}\text { Greb } \\
6\end{array}$ & $\begin{array}{l}\text { Greb } \\
7\end{array}$ & $\begin{array}{l}\text { Greb } \\
8\end{array}$ & $\begin{array}{l}\text { Greb } \\
9 \\
\end{array}$ & $\begin{array}{l}\text { Greb } \\
10\end{array}$ \\
\hline Active & $\begin{array}{l}2.27 \\
( \pm .82)\end{array}$ & $\begin{array}{l}2.21 \\
( \pm .95)\end{array}$ & $\begin{array}{l}2.22 \\
( \pm 1.0)\end{array}$ & $\begin{array}{l}2.57 \\
( \pm 1.9)\end{array}$ & $\begin{array}{l}3.61 \\
( \pm 1,1)\end{array}$ & $\begin{array}{l}3.5 \\
( \pm .91)\end{array}$ & $\begin{array}{l}3.6 \\
( \pm 1.2)\end{array}$ & $\begin{array}{l}2.7 \\
( \pm 1,2)\end{array}$ & $\begin{array}{l}1.7 \\
( \pm .09)\end{array}$ & $\begin{array}{l}3.7 \\
( \pm 1.0)\end{array}$ \\
\hline Passive & $\begin{array}{l}3.01 \\
( \pm 1.1)\end{array}$ & $\begin{array}{l}2.67 \\
( \pm 1.1) \\
\end{array}$ & $\begin{array}{l}2.83 \\
( \pm 1.16)\end{array}$ & $\begin{array}{l}3.2 \\
( \pm 1.1)\end{array}$ & $\begin{array}{l}3.7 \\
( \pm .98) \\
\end{array}$ & $\begin{array}{l}3.8 \\
( \pm 1.0) \\
\end{array}$ & $\begin{array}{l}3.9 \\
( \pm 1.0)\end{array}$ & $\begin{array}{l}2.9 \\
( \pm 1.3)\end{array}$ & $\begin{array}{l}1.8 \\
( \pm 1.1) \\
\end{array}$ & $\begin{array}{l}3.5 \\
( \pm 1.1) \\
\end{array}$ \\
\hline$t / p$ & $\begin{array}{l}-5.22 * \\
\mathbf{p}<.001\end{array}$ & $\begin{array}{l}-3.26^{*} \\
\mathbf{p}<.01\end{array}$ & $\begin{array}{l}-3.91 * \\
\mathbf{p}<.001\end{array}$ & $\begin{array}{l}-3.80 * \\
\mathbf{p}<.001\end{array}$ & $p=n . s$. & $p=n . s$. & $p=n . s$. & $p=n . s$. & $p=n . s$. & $p=n . s$. \\
\hline $\begin{array}{l}\text { Outdoor } \\
\text { Activity } \\
\text { Frequency }\end{array}$ & $\begin{array}{l}\text { Greb } \\
1\end{array}$ & $\begin{array}{l}\text { Greb } \\
2\end{array}$ & $\begin{array}{l}\text { Greb } \\
3\end{array}$ & $\begin{array}{l}\text { Greb } \\
4\end{array}$ & $\begin{array}{l}\text { Greb } \\
5\end{array}$ & $\begin{array}{l}\text { Greb } \\
6\end{array}$ & $\begin{array}{l}\text { Greb } \\
7\end{array}$ & $\begin{array}{l}\text { Greb } \\
8\end{array}$ & $\begin{array}{l}\text { Greb } \\
9\end{array}$ & $\begin{array}{l}\text { Greb } \\
10\end{array}$ \\
\hline Low & $\begin{array}{l}2.28 \\
( \pm .80) \\
\end{array}$ & $\begin{array}{l}2.24 \\
( \pm .97) \\
\end{array}$ & $\begin{array}{l}2.27 \\
( \pm 1.0)\end{array}$ & $\begin{array}{l}2.7 \\
( \pm 1.2) \\
\end{array}$ & $\begin{array}{l}3,6 \\
( \pm .93) \\
\end{array}$ & $\begin{array}{l}3.7 \\
( \pm .93) \\
\end{array}$ & $\begin{array}{l}3.6 \\
( \pm 1.1)\end{array}$ & $\begin{array}{l}2.9 \\
( \pm 1,2)\end{array}$ & $\begin{array}{l}1.8 \\
( \pm .09) \\
\end{array}$ & $\begin{array}{l}3.6 \\
( \pm 1.1) \\
\end{array}$ \\
\hline High & $\begin{array}{l}3.01 \\
( \pm 1.1)\end{array}$ & $\begin{array}{l}.7 \\
( \pm .99) \\
\end{array}$ & $\begin{array}{l}2.84 \\
( \pm 1.2) \\
\end{array}$ & $\begin{array}{l}3.0 \\
( \pm 1.1)\end{array}$ & $\begin{array}{l}3.7 \\
( \pm 1.1) \\
\end{array}$ & $\begin{array}{l}3.6 \\
( \pm 1.0) \\
\end{array}$ & $\begin{array}{l}3.9 \\
( \pm 1.1)\end{array}$ & $\begin{array}{l}2.7 \\
( \pm 1.4) \\
\end{array}$ & $\begin{array}{l}1.8 \\
( \pm 1.1) \\
\end{array}$ & $\begin{array}{l}3.6 \\
( \pm 1.0) \\
\end{array}$ \\
\hline$t / p$ & $\begin{array}{l}-5.84 * \\
p<.001\end{array}$ & $\begin{array}{l}-3.26^{*} \\
p<.001\end{array}$ & $\begin{array}{l}-3.51^{*} \\
\mathrm{p}<.01\end{array}$ & $p=n . s$. & $p=n . s$. & $p=n . s$. & $\begin{array}{l}-2.21 \\
p<.05\end{array}$ & $p=n . s$. & $p=n . s$. & $p=n . s$. \\
\hline
\end{tabular}

Note. $* \mathrm{p}<.01$

According to the variable of yoga experience, we found statistically significant differences for three Greb items: Greb1, participation in environmental events $(\mathrm{t}=-4.85, \mathrm{p}<.001)$; Greb3, participation in meetings of environmental organizations $(\mathrm{t}=-2.94, \mathrm{p}<.01)$; and Greb5, seeking information on addressing environmental pollution $(\mathrm{t}=-2.7, \mathrm{p}<.01)$. In all cases, the high experience group scored higher than the low experience group.

According to the variable of active leisure participation, variable statistically significant differences were found for four of the ten Greb items: Greb1, participation in environmental events $(\mathrm{t}=-5.22, \mathrm{p}<.001)$; Greb 2, participation in actions of cleaning up forests, beaches or outdoor areas $(\mathrm{t}=-3.26, \mathrm{p}<.01)$; Greb 3, participation in meetings of environmental organizations $(\mathrm{t}=-3.91, \mathrm{p}<.01)$; and Greb4, participation in tree planting actions $(\mathrm{t}=-3.8$, $\mathrm{p}<.01)$. In all items, the group with high activity scored higher than the group with low activity.

The variable of the frequency of participation in outdoor activities showed statistically 
significant differences for four of the ten Greb items: Greb1, participation in environmental events $(\mathrm{t}=-5.84, \mathrm{p}<.001)$; Greb2, participation in actions of cleaning up forests, beaches or outdoor areas $(\mathrm{t}=-3.26, \mathrm{p}<.01)$; Greb3, participation in meetings of environmental organizations $(\mathrm{t}=-3.51, \mathrm{p}<.01)$; and $\mathrm{Greb} 7$, preferring products that have a lower polluting effect $(\mathrm{t}=-2,21 \mathrm{p}<.01)$. In all items, the high outdoor participation group scored higher than the low outdoor participation group.

A two-way analysis was also conducted to estimate relationships among the three independent variables and the ten GREB items. The analysis did not reveal any statistically significantly different results.

\section{Discussion}

The natural environment is facing the effects of human recklessness with impunity, and much interest has been paid to this influence in recent years. Environmental practices become essential as environmental problems grow and cause imbalances in nature. The present study explored how yoga and environmental sustainability are related, specifically whether participating in yoga practice changes people's daily behaviour towards the environment. The results supported the main and secondary objectives of the study, indicating that people who participate more often in yoga practices exhibit more environmental behaviour. In addition, the results showed that environmental behaviour is positively associated with the frequency of participation in sports during leisure time and the frequency of participation in outdoor activities.

The findings related to the main objective of the study revealed differences in participation in environmental activities, the coexistence of individuals and groups addressing environmental issues, and the use of products that do not pollute the environment. These findings are attributable to yoga practice uniting practitioners and placing them in contact with nature and the environment (Brinkley, 2010).

Yogic philosophy teaches union and interdependence, not only with oneself but with nature and the entire world, thus creating a circle of life in which harmony is fragile and depends on coexistence with other people and the environment. According to Patanjali, this harmony is achieved through the application of eight steps involving deepening thought and consciousness, removing obstacles, and creating behaviours that promote positive psychology, inner peace, and consequently balance in nature and the world. The yogic lifestyle can serve as a model for preserving the environment and ecology. The translation of individual ethical principles from the philosophy of yoga to environmental behaviour is the initial step in addressing ecological crisis.

Patanjali's eight-step practice, particularly meditation, Yamas, Niyamas and body cleansing through asanas, appears to work. Mindfulness mediation brings awareness to the present and helps people manage tension, emotions and behaviours more effectively. These benefits can be extended to a friendlier attitude towards the rest of the world and the environment to which humans are inextricably linked. Generally, mindfulness mediation makes us more aware of ourselves and our actions, thus leading to behaviours with meaning and purpose, 
such as recycling, and the use of water and energy. In addition, mindfulness mediation involves developing attitudes of kindness, compassion and gratitude, which can translate to eco-friendly behaviour. Yoga is truly a union, and its practice can incorporate a universal vision towards a sustainable future.

Furthermore, Yamas and Niyamas - the ethical codes and guidelines for self-responsibility, and serving others and the environment - teach people to be mindful of their own actions; provide guidelines for how to change overconsumption habits and violent lifestyles; and remind people to offer respect and care, both during and outside mat practice. Practicing Yamas and Niyamas can become strong motivators for adapting an eco-friendly lifestyle.

A secondary objective of this study involved participation in sport activities during leisure time. We observed differences in participation in environmental events and clean-up, the coexistence of groups and individuals addressing environmental issues, and information on solutions to environmental pollution. This finding was attributed to the realization that the well-being of the environment is associated with one's own well-being (Zafeiroudi \& Hatzigeorgiadis, 2014). By taking care of individual well-being through exercise and engaging in sports, practitioners become more aware of their health and the environmental factors affecting it. Beyond benefiting from improvements in psychology through the practice of yoga and exercise in general, and the relief of daily stress, people become willing to address new matters of direct concern (Thurston \& Bloyce, 2020).

Finally, the last objective of the study addressed the frequency of participation in outdoor activities. We observed differences in aspects such as participation in environmental activities and clean-up, the coexistence of groups and individuals addressing environmental issues, and the purchase of products that pollute the environment less. Outdoor activities occur in the natural environment. In addition to benefiting from physical improvement and restoration of health, people gain information and education about nature. Thus, practitioners are informed about nature and realize its quality and value. These results support findings from previous studies (Zafeiroudi, 2020; Harbrow, 2019; Pavlidis, Zafeiroudi \& Kouthouris, 2018) indicating that frequent contact with the environment helps people understand their interactions with nature and thus become willing to take action in environmental protection.

Yoga is a kind of practice that occurs indoor or/and outdoor and is reported as a worldwide leisure activity (Thurston \& Bloyce, 2020). Yoga has already replaced many of the sports and activities in which people used to participate during their free time. The results confirm previous research (Zafeiroudi, 2020; Pavlidis, Zafeiroudi, \& Kouthouris, 2018; Zafeiroudi \& Hatzigeorgiadis, 2014) that leisure experiences are associated with well-being, quality of life and affect ecosystemic and ekistic relationships. According to the findings, the practice of yoga as a leisure activity is beyond self and physical body and is directly related to others such as the environment and its protection. Yoga though its techniques generate new exercise habits and free time lifestyles that support ecological behaviours, green living and a more sustainable future.

The key to protecting the environment lies in changing individual behaviour (Betal, 2008). According to Zafeiroudi and Hatzigeorgiadis (2014) to enjoy individual well-being, people 
must first be interested in the well-being of the environment, which is inextricably associated with a good quality of life. Individual improvement occurs with physical exercise, which confers both physical and psychological benefits (Zafeiroudi \& Hatzigeorgiadis, 2014). Although yoga is an Eastern type of exercise, it involves more than just physical exercise. The yogic way of life developed in Indian philosophy aims to dispel negative attitudes and habits. Beyond the physical aspects, spiritual practice and the assimilation of a code of moral values that lead to changes in individuals' core personalities are promoted (Betal, 2008). The sustainable way of life that yoga aims to cultivate can pass through individuals and lead to action towards environmental issues and conservation (Bhagwat, 2008).

The development of environmental behaviour is highly important and ideally is cultivated from a young age, to promote the development of integrated personalities and informed citizens (Zafeiroudi, Kakarinou, \& Kouthouris, 2015). Environmentally responsible citizens live in the present and recognize how the environment works, including the problems and environmental issues that exist, but also want to actively contribute to the protection of nature, as they know how to achieve it. Thus, through programs and practices of environmental awareness and education, individuals become acquainted with environmental issues and form a cognitive background allowing them to be continually informed and to follow developments in environmental issues.

Meditation develops reflection and critical thinking, which help cultivate positive attitudes, beliefs and skills that prompt individuals to take action. Participation in organized environmental activities and cooperation with other environmental stakeholders enables people to take initiatives to be socially active and to contribute to overall progress. By realizing the connection between quality of life and the environment, people become interested in their contributions to ecological balance and sustainable development. Environmental behaviour does not involve large acts can instead involve small daily conscious actions - such as recycling, conservation of water and energy, and avoiding overconsumption - that stem from knowledge of the effects of our actions on nature.

Humans are born into the natural environment and are inextricably associated with it. With the development of science and technology, and the quest to achieve prosperity, humans have caused natural and environmental disasters, including several 'ecological crises' whose effects have attracted interest in recent years. Substantial effort has been devoted to raising public awareness of environmental problems. The present study aimed to examine the environmental behaviours of people participating in yoga programs, sports and outdoor activities during their free time. The focus of our research was on yoga, because it is not only a physical practice but also a practice of moral and spiritual cultivation. Yoga is built on a philosophy thousands of years old that can take root in individuals' daily behaviours. The individual moral values and codes of conduct taught by the philosophy of yoga can translate to the moral behaviour that individuals must have towards the environment.

The findings of the present work create possibilities and opportunities for further research and may aid in planning new theoretical studies. More specifically, they may facilitate future research in a wider population participating in holistic practice of yoga, including 
experimental and control groups. The individual values intrinsic to the philosophy of yoga appear to translate to protective behaviours towards the environment. Our findings also suggest that yoga practice may be an effective supplement and a more challenging alternative to programs currently run by leisure, environmental and social associations, such as the Green Yoga Association.

\section{References}

Agarwal, S. K. (2018). Evidence based health benefits of yoga: Research data validating 100 health related improvements commonly attributed to yoga. Create Space independent publishing platform, South Caroline.

Amel, E. L., Manning, C. M., \& Scott, B. A. (2009). Mindfulness and sustainable behavior: Pondering attention and awareness as means for increasing green behavior. Ecopsychology, 1(1), 14-25. https://doi.org/10.1089/eco.2008.0005

Basavaraddi, I. (2015). Yoga: its origins, history and development. [Online] Available: https://www.mea.gov.in/search-result.htm?25096/Yoga:_su_origen,_historia_y_desarrollo

Betal, C. (2008). Conservation of ecology and environment through yogic lifestyle. Journal of Environmental Research and Development, 2(4), 905-912.

Bhagwat, S. A. (2008). Yoga and Sustainability. Joy: The Journal of Yoga, 7(1), 1-14. https://doi.org/10.4103/0973-6131.37570

Brinkley, M. (2010). Green Yoga. [Online] Available:

http://files.site-fusion.co.uk/webfusion99708/file/greenyoga-anessaybymandybrinkley.pdf

Carlson, E. N. (2013). Overcoming the barriers to self-knowledge: Mindfulness as a path to seeing yourself as you really. Perspectives on Psychological Science, 8(2), 173-186.

https://doi.org/10.1177/1745691612462584

Cramer, H., Sibbritt, D., Park, C. L., Adams, J., \& Lauche, R. (2017). Is the practice of yoga or meditation associated with a healthy lifestyle?: Results of a national cross-sectional survey of 28,695 Australian women. Journal of Psychosomatic Research, 101, 104-109.

https://doi.org/10.1016/j.jpsychores.2017.07.013

Ericson, T., Kjønstad, B. G., \& Barstad, A. (2014). Mindfulness and sustainability. Ecological economics, 104, 73-79. https://doi.org/10.1016/j.ecolecon.2014.04.007

Harbrow, M. (2019). Visitors as advocates. A review of the relationship between participation in outdoor recreation and support for conservation and the environment. [Online] Available: https://www.doc.govt.nz/globalassets/documents/science-and-technical/sfc333entire.pdf

Hartranft, C. (2002). The Yoga-Sutra of Patanjali: A New Translation with Commentary. Shambhala, Boston.

Hill, M. K. (2020). Understanding environmental pollution (4th ed.). University press Cambridge, U.K. https://doi.org/10.1017/9781108395021 


\section{Macrothink \\ Environmental Management and Sustainable Development \\ ISSN 2164-7682 \\ 2021, Vol. 10, No. 3}

Iyengar, B. K. S. (1979). Light on Yoga. Schocken books, USA.

Kang, Y., Gruber, J., \& Gray, J. R. (2013). Mindfulness and De-Automatization. Emotion Review, 5(2), 192-201. https://doi.org/10.1177/1754073912451629

Kumar, M. A. (2017). An Introduction to Yoga Philosophy. An Annotated Translation of the Yoga Sutras. Routledge, Taylor \& Francis Group, New York.

Malhotra, A. K. (2001). An Introduction to Yoga Philosophy: An annotated translation of the Yoga Sutras (1st ed.). Routledge. https://doi.org/10.4324/9781315262635

O'Brien, C. (2008). Sustainable happiness: How happiness studies can contribute to a more sustainable future. Canadian Psychology/Psychologie canadienne, 49(4), 289-295.

https://doi.org/10.1037/a0013235

Pandey, A., Ajinkya V. N., \& Rajesh C. (2017). What Yoga got to do with Positive Psychology: A Study of the Connections and Associated Mechanism. Academy of Management Proceedings, 2017 (1), 16831.

https://doi.org/10.5465/AMBPP.2017.16831abstract

Pavlidis, G., Zafeiroudi, A., \& Kouthouris, C. (2018). Investigating trekkers' environmental behavior that visit Olympus Mountain refuges. Journal of Sport \& Recreation Management, 15(1), 1-21.

Varambally, S., \& Gangadhar, B. N. (2016). Current status of yoga in mental health services. International Review of Psychiatry, 28(3), 233-235.

https://doi.org/10.3109/09540261.2016.1159950

Sumner, J. (2018). Eating our way to sustainability? Leisure, food and community economic development. Sustainability, 10(5), 1-9. https://doi.org/10.3390/su10051422

Thurston, M., \& Bloyce, D. (2020) A quest for relaxation? A figurational analysis of the transformation of yoga into a global leisure time phenomenon. Sport in Society, 23(10), 1615-1629. https://doi.org/10.1080/17430437.2020.1814574

Tibbs, H. (2011). Changing cultural values and the transition to sustainability. J. Futur. Stud., 15(3), 13-32.

Vago, D. R. (2013). Mapping modalities of self-awareness in mindfulness practice: a potential mechanism for clarifying habits of mind. Ann. N.Y. Acad. Sci., 1307, 28-42.

https://doi.org/10.1111/nyas.12270

Weisner, M. L., \& Cameron, M. M. (2020). Enhanced sensory awareness and environmental behavior in South Florida. Worldviews: Global Religions, Culture, and Ecology, 24(1), 58-80. https://doi.org/10.1163/15685357-02401101

Zafeiroudi, A., \& Hatzigeorgiadis, A. (2012). Psychometric investigation of 'Environmental Responsible Behavior scale during participation in sport leisure. Sports \& Recreation Management, 8(1), 23-40. 


\section{Macrothink}

Environmental Management and Sustainable Development

ISSN 2164-7682

2021, Vol. 10, No. 3

Zafeiroudi, A., Kakarinou, V., \& Kouthouris, C. (2015). Environmental Responsibility and the level of Physical Activity in Secondary Education. The case of Environmental Education Centre of Paranesti. Journal of Sport \& Recreation Management, 12(2), 19-35.

Zafeiroudi, A. (2018a). Yoga Philosophy and the eight steps of Patanjali: The analysis of Niyamas and their application to everyday life. Journal of Sport \& Recreation Management, 15(2), 40-56.

Zafeiroudi, A. (2018b). Hatha Yoga: The importance of Yamas and their application from theory to practice. Journal of Sport \& Recreation Management, 15(1), 64-76.

Zafeiroudi, A. (2020). Enhancing Adolescents' Environmental Responsibility Through Outdoor Recreation Activities. Academic Journal of Interdisciplinary Studies, 9(6), 43-55.

https://doi.org/10.36941/ajis-2020-0110

Zafeiroudi, A. (2021). Teaching yoga. Basic and intermediate level. University Publications of Thessaly, Volos, Greece.

Zafeiroudi, A., \& Hatzigeorgiadis, A. (2013). Environmental Responsibility in Secondary School Students: Development, Validation \& Relationships between Environmental Scales. Inquiries in Sport \& Physical Education, 12(3), 253-264.

Zafeiroudi, A., \& Hatzigeorgiadis, A. (2014). The effects of an outdoor pursuit's intervention program on adolescents' environmental beliefs. International Journal on Advances in Education Research, 1(3), 106-118.

\section{Copyrights}

Copyright for this article is retained by the author(s), with first publication rights granted to the journal.

This is an open-access article distributed under the terms and conditions of the Creative Commons Attribution license (http://creativecommons.org/licenses/by/4.0/) 